\title{
ON THE HEMOLYTIC ACTION OF O-AMINOPHENOL AZO-PROTEIN DERIVATIVES
}

\author{
By Ryo ITO, Saburo KOSHIMURA and Shigematsu FUJITA \\ The Laboratories of the Pharmacological and Pharmaceutical Department \\ and Chemical Department of the Research Institute of Tuberculosis, \\ Kanazawa Medical University.
}

Our preliminary paper appeared in October, 1948 (1) reported, in so far as we knew, the first experimental evidence that O.A.-azo-tuberculin $\dagger$ gives powerful tuberculin skin reaction in tuberculous guinea-pigs, and has very low toxicity for guineapigs infected with a human strain of tubercle bacilli.

While engaged in the study of the pharmacological action of O.A.-azo-tuberculin derivatives, we have recently noticed a curious phenomenon indicating that O. A.azo-tuberculin dissolves the red blood cells. $\dagger \dagger$

In view of this finding, it was also of interest to study the effect of various aminophenol azo-protein derivatives upon red blood cells. For this purpose, a number of azo-protein derivatives were prepared and tested for their hemolytic activity, and the results are reported in the present communication.

\section{Methods, Materials and Terminology}

I. Materials tested for their hemolytic activity.-

A. Azo-proteins :

* 1. o-Aminophenol azo-albumin (=2-Hydroxyphenyl-azo-albumin)

** 2. $p$-Aminophenol azo-albumin

** 3. Sulfanilic acid azo-albumin

* 4. Anthranilic acid azo-albumin

* 5. o-Aminophenol azo-albumin (prepared from horse serum)

* 6. o-Aminophenol azo-globulin (prepared from horse serum)

* 7. o-Aminophenol azo-albumin egg (prepared from Egg Albumin "Merck")

* 8. $o$-Aminophenol- $\beta$-d-glucoside azo-globulin (prepared from horse serum globulin)

$\dagger$ The term, O.A.-azo-tuberculin, is employed to denote " $o$-aminophenol azo-tuberculin ( $=0$ hydroxyphenyl-azo-tuberculin)", an azo-tuberculin derivative obtained by coupling diazotized $o$-aminophenol with purified tuberculin.

†† The detailed data will be published in the near future.

* S. Koshimura will make a separate report on the chemical phases of these preparations, as soon as the work to clarify the correlation between the diazotization grade of the protein and the grade of hemolytic power of the protein diazotized is completed.

** $p$-Aminophenol azo-albumin, sulfanilic acid azo-albumin and anthranilic acid azo-albumin were prepared according to the Landsteiner and Lampl's procedures (Biochem. Z., 86, 343, 1918; Z. Immunit.-forsch., 26, 293, 1917). [cf. J. Marrack ; The Chemistry of Antigens and Antibodies, Med. Res. Council, London, Spec. Rep. No. 194. 1938.] 
* 9. 4-Bromo-2-aminophenol azo-protein

* 10. 3-Amino-4-hydroxybenzenesulfonic acid azo-protein

* 11. 4-Hydroxy-2-aminophenol azo-protein

* 12. 4-Methyl-2-aminophenol azo-protein

(prepared from fresh horse serum)

* 13. 5-Nitro-2-aminophenol azo-protein

*.14. 3-Amino-4-hydroxybenzenecarbonic acid azo-protein

* 15. 7-Amino-8-hydroxyquinoline-5-sulfonic acid azo-protein

B. Sources of proteins :

16. Albumin sanguinis "Kahlbaum"

17. Albumin (prepared from horse serum)

18. Globulin (prepared from horse serum)

19. Egg Albumin "Merck"

C. Miscellaneous :

20. o-Aminophenol

21. p-Aminophenol

22. Sulfanilic acid

13. o-Aminobenzoic acid (Anthranilic acid)

24. Saponin (Saponin "Merck" has been used throughout for control.)

II. Original solution of the materials tested.-

The materials to be tested were all diluted with $0.85 \% \mathrm{NaCl}$ solution.

Protein materials :

$20.0 \mathrm{mg}$ of the azo-protein derivative (undiazotized protein also) to be tested was dissolved in $1.8 \mathrm{cc}$ of $0.85 \%$ salt solution with the aid of one or two drops of normal sodium hydroxide and the solution is then neutralized with dilute hydrochloric acid. This is then brought to $2.0 \mathrm{cc}$ by the addicion of $0.85 \%$ salt solucion and adjusted to $\mathrm{pH}$ of 7.0 7.8 with the aid of indicators, as specified on Table 2. (The excess of the $\mathrm{NaOH}$ or $\mathrm{HCl}$ solution must be rigidly avoided.) Thus the concentration of the original solution was $1: 100$.

Non-protein materials :

$20.0 \mathrm{mg}$ of $o$-aminophenol ( $p$-aminophenol also) was dissolved in $1.0 \mathrm{cc}$ of $0.85 \%$ salt solucion.

$20.0 \mathrm{mg}$ of sulfanilic acid (anthranilic acid also) was dissolved in $2.0 \mathrm{cc}$ of $0.85 \%$ salt . solution with the aid of a small amount of normal sodium hydroxide.

III. Test for hemolytic power

The method is the same as that described in the earlier reports (2)-(5): Serial dilutions of the material to be tested were made in $0.85 \% \mathrm{NaCl}$ solution (che total. volume of the each test tube was $1.0 \mathrm{cc}$ ) and $1.0 \mathrm{cc}$ of $1 \%$ suspension of 3 time washed rabbit's red blood cells was added to each tube. All tubes were thoroughly shaken, placed in an incubator at $37^{\circ} \mathrm{C}$ for 2 hours, and then placed in an ice-box for 22 hours.

\section{Experimental Data}

Table 1 represents the results of hemolysis experiments carried out with $o$-aminophenol azo-albumin prepared from Albumin sanguinis "Kahlbaum", $o$-aminophenol, "Albumin sanguinis "Kahlbaum" and saponin. 
It will be noted from this table that $o$-aminophenol azo-albumin showed hemolytic activity up to a dilution of $1: 50,000$ at the end of 24 hours, while neither $o$-aminophenol nor Albumin sanguinis "Kahlbaum" showed any appreciable hemolytic activity. In the experiment with saponin, the hemolytic effect was obtained up to a dilution of $1: 500,000$.

Table 1. The effect in vitro of $\boldsymbol{o}$-aminophenol Azo-protein, $\boldsymbol{o}$-aminophenol, albumin and saponin upon erythrocytes.

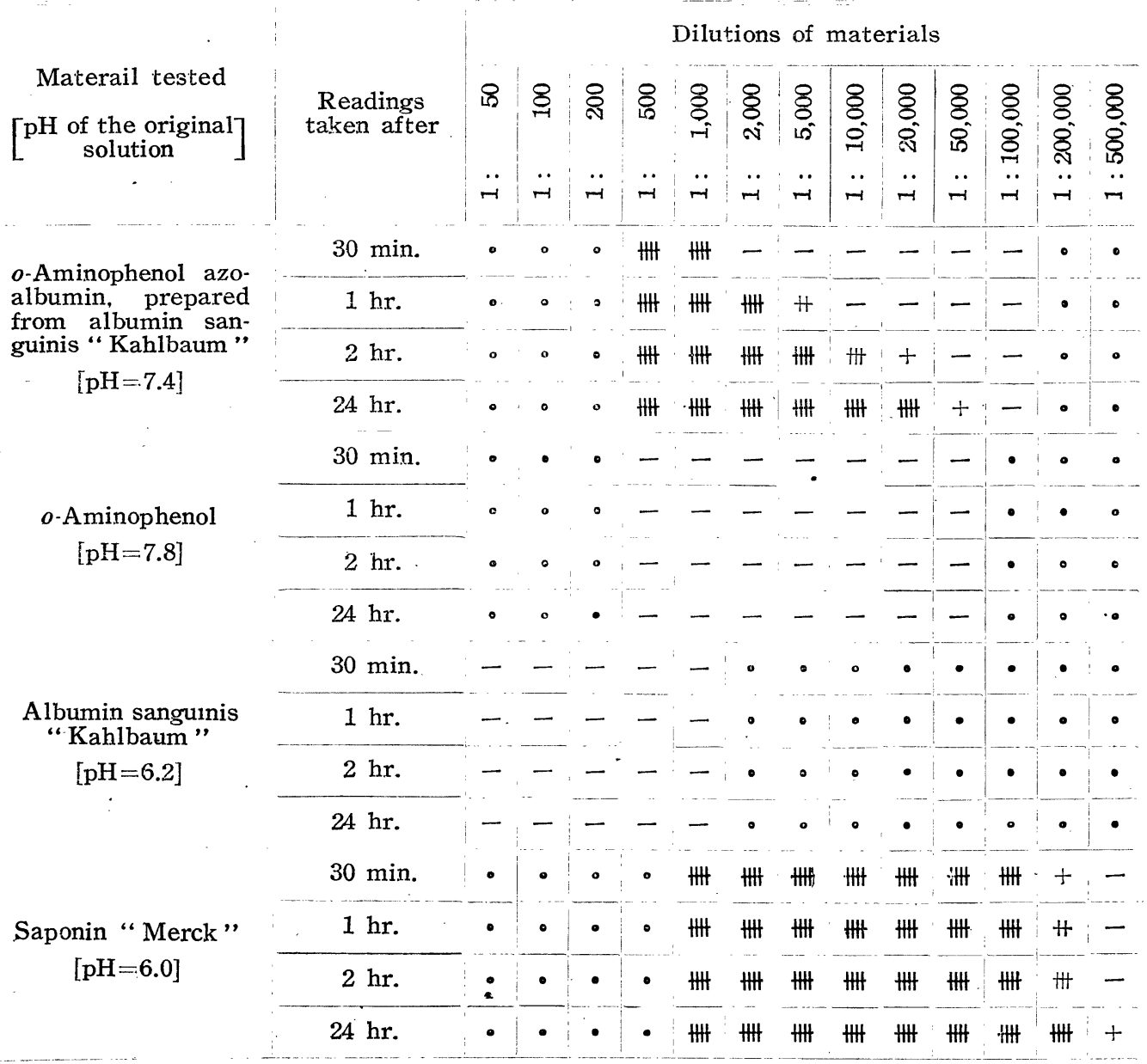

Notes: $1 \mathrm{cc}$ of $1 \%$ washed rabbit's red cells suspension was added to $1 \mathrm{cc}$ of the graduated dilutions of the material.

HI indicates complete hemolysis; $\mathrm{H}, \mathrm{H},+$ and \pm indicate partial hemolysis; - indicates no hemolysis.

Similar results were obtained in the experiments with $o$-aminophenol azo-albumin prepared from horse albumin, albumin prepared from horse serum, and $o$-aminophenol.

Table 2 represents the summaries of a large number of such comparative hemolysis experiments carried out upon 15 azo-protein derivatives, 4 proteins, and $o$-amino- 
Table 2. Summary of hemolysis experiments.

\begin{tabular}{|c|c|c|c|c|c|c|c|c|c|c|c|c|c|c|}
\hline \multirow[b]{2}{*}{ No. } & \multirow[b]{2}{*}{$\begin{array}{l}\text { Materials } \\
\text { tested } \\
{\left[\begin{array}{c}\mathrm{pH} \text { of the original } \\
\text { solution }\end{array}\right]}\end{array}$} & \multicolumn{7}{|c|}{ Reading the results: } & \multicolumn{4}{|c|}{ After 24: hours } & \multirow{2}{*}{\multicolumn{2}{|c|}{ 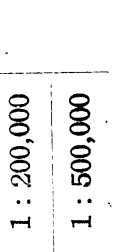 }} \\
\hline & & $\ddot{r}$ & $\underset{+1}{8}$ & $\ddot{r}$ & $\ddot{-1}$ & $\begin{array}{c}8 \\
\varnothing \\
-i \\
\ddot{r i}\end{array}$ & $\begin{array}{l}8 \\
8 \\
\text { N } \\
\ddot{H}\end{array}$ & $\begin{array}{c}8 \\
8 \\
10 \\
\ddot{10}\end{array}$ & $\begin{array}{l}8 \\
8 \\
\ddot{1} \\
\ddot{-1}\end{array}$ & $\begin{array}{l}8 \\
8 \\
8 \\
8 \\
\ddot{n} \\
\ddot{n}\end{array}$ & $\begin{array}{l}8 \\
\delta \\
\dot{\circ} \\
\ddot{n} \\
\ddot{r}\end{array}$ & $\begin{array}{l}8 \\
8 \\
8 \\
\stackrel{-1}{r} \\
\ddot{7}\end{array}$ & & \\
\hline 1 & $\begin{array}{l}\text { o-Aminophenol azo-albumin } \\
\text { (Albumin sanguinis "Kahl- } \\
\text { baum") } \quad[\mathrm{pH}=7.4]\end{array}$ & 。 & 。 & 。 & HW & HW & 洲 & 料 & tit & 册 & + & - & . & - \\
\hline 2. & $\begin{array}{l}\text { p-Aminophenol azo-albumin } \\
\text { (Albumin sanguinis " Kahl- } \\
\text { baum") } \\
\end{array}$ & - & 。 & 。 & - & - & - & - & - & - & - & - & - & • \\
\hline 3 & $\begin{array}{l}\text { Sulfanilic acid azo-albumin } \\
\text { (Albumin sanguinis "Kahl- } \\
\text { baum") } \\
\qquad[\mathrm{pH}=7.6]\end{array}$ & - & - & o & - & - & - & - & $一$ & - & - & - & $\bullet$ & - \\
\hline 4 & $\begin{array}{l}\text { Anthranilic acid azo-albumin } \\
\text { (Albumin sanguinis " Kahl- } \\
\text { babm") } \quad[\mathrm{pH}=7.8]\end{array}$ & • & - & - & - & - & - & - & - & - & - & $\circ$ & - & • \\
\hline 5 & $\begin{array}{l}o \text {-Aminophenol azo-albumin } \\
\text { (Horse serum albumin) } \\
\qquad[\mathrm{pH}=7.7]\end{array}$ & - & - & - & 册 & 冊 & 册 & 冊 & HWl & H & - & - & - & - " \\
\hline 6 & $\begin{array}{l}o \text {-Aminophenol azo-globulin } \\
\text { (Horse serum globulin) } \\
\qquad[\mathrm{pH}=7 \mathrm{7}]\end{array}$ & $\bullet$ & - & $\bullet$ & 册 & HI & H & $H$ & + & - & - & - & - & • \\
\hline 7 & $\begin{array}{l}o \text {-Aminophenol azo-albumin } \\
\text { egg (Egg Albumin "Merck") } \\
\qquad[\mathrm{pH}=7.6]\end{array}$ & • & $\begin{array}{l}\mathbf{0} \\
.\end{array}$ & • & 册 & HAt & HW & 册 & 册 & H & + & - & . & • \\
\hline 8 & $\begin{array}{l}o \text {-Aminophenol- } \beta \text {-d-glucoside } \\
\text { azo-globulin (Horse serum } \\
\text { globulin) } \\
{[\mathrm{pH}=7.5]}\end{array}$ & • & - & • & - & - & - & - & - & - & - & • & • & • \\
\hline 9 & $\begin{array}{l}\text { 4-Bromo-2-aminophenol azo- } \\
\text { protein (Horse serum) } \\
\qquad[\mathrm{pH}=7.8]\end{array}$ & : & • & • & 冊 & 朿 & 冊 & HI & + & - & - & • & • & - \\
\hline 10 & $\begin{array}{l}\text { 3-Amino-4-hydroxybenzene- } \\
\text { sulfonic acid azo-protein } \\
\text { (Horse serum) } \\
\qquad[\mathrm{pH}=7.6]\end{array}$ & - & • & • & - & - & - & - & - & - & - & • & • & \\
\hline & $\begin{array}{l}\text { 4-Hydroxy-2-aminophenol azo- } \\
\text { protein (Horse serum) } \\
\qquad \quad[\mathrm{pH}=7.5]\end{array}$ & • & • & - & - & - & - & - & - & ${ }^{-}$ & - & • & - & • \\
\hline
\end{tabular}


Table 2. Summary of hemolysis experiments (continued).
Dilutions of materials
No. Materials
tested
$\left[\begin{array}{c}\mathrm{pH} \text { of the original } \\ \text { solution }\end{array}\right]$
4-Methyl-2-aminophenol azo- protein (Horse serum)

$$
[\mathrm{pH}=7.6]
$$
5-Nitro-2-aminophenol protein (Horse serum)
azo- $[\mathrm{pH}=7.1]$
3-Ámino-4-hydroxybenzene- carbonic acid azo-protein (Horse serum) $[\mathrm{pH}=7.1]$
7-Amino-8-hydroxyquinoline- 5 -sulfonic acid azo-protein (Horse serum)

$$
[\mathrm{pH}=7.7]
$$

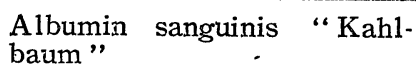

$$
[\mathrm{pH}=6.2]
$$
Horse serum albumin

$$
[\mathrm{pH}=5.8]
$$
Horse serum globulin

$$
[\mathrm{pH}=7.8]
$$
Egg albumin " Merck"
$o$-Aminophenol

$$
[\mathrm{pH}=5.8]
$$

$$
[\mathrm{pH}=7.8]
$$
21
p-Aminophenol

$$
[\mathrm{pH}=5.5]
$$
22
Sulfanilic acid

$$
[\mathrm{pH}=7.0]
$$
$o$-Aminobenzoic acid (An- thranilic acid)

$$
[\mathrm{pH}=6.5]
$$
Reading the results: After 24 hours
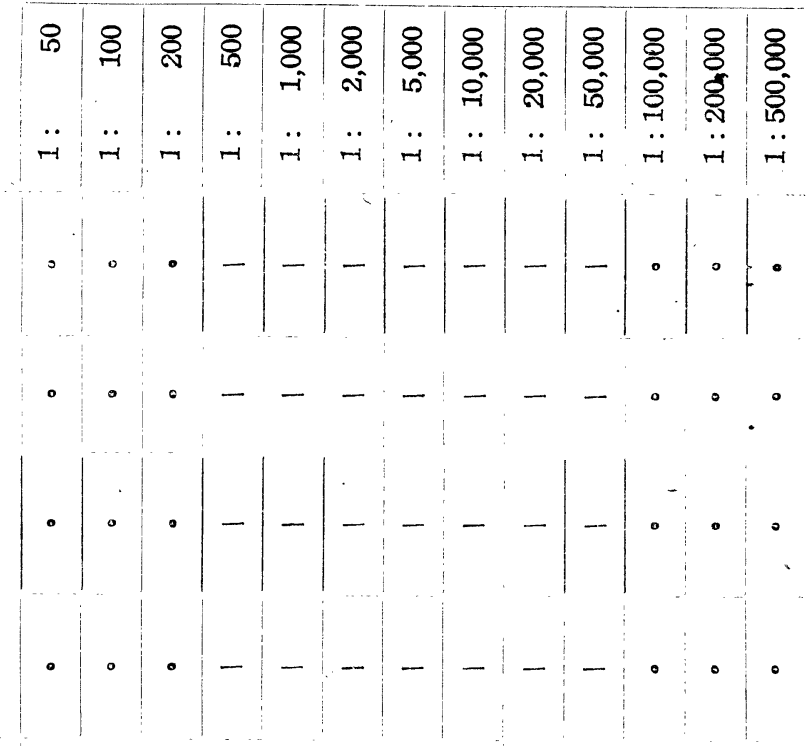
phenol, $p$-aminophenol, sulfanilic acid, anthranilic acid and saponin, in relation to their structural formulas. Special attention may here be directed to following points :

1. o-Aminophenol azo-albumin, $o$-aminophenol azo-globulin, $o$-aminophenol azo-albumin egg and 4-bromo-2-aminophenol azo-protein were all found to have distinct hemolytic activity.

By contrast, 3-amino-4-hydroxybenzenesulfonic acid azo-protein, 4-hydroxy-2aminophenol azo-protein, 4-methyl-2-aminophenol azo-protein, 5-nitro-2-aminophenol azo-protein, 3-amino-4-hydroxybenzenecarbonic acid azo-protein and 7-amino8-hydroxyquinoline-5-sulfonic acid azo-protein, all do not share the hemolytic pro-, perties of the above-mentioned $o$-aminophenol azo-protein derivatives.

2. $p$-Aminophenol azo-albumin sulfanilic acid azo-albumin and anthranilic acid azoalbumin, all contrasted strongly with $o$-aminophenol azo-proteins in failing to cause hemolysis.

It is also particularly noteworthy that $\alpha$-aminophenol- $\beta$-d-glucoside azo-globulin was found to be entirely without hemolytic effect.

3. Note that no hemolysis was observed in any of the series. of dilutions made from the undiazotized proteins, namely Albumin sanguinis "Kahlbaum", Egg albumin "Merck", horse serum albumin and horse serum globulin. Moreover simple organic compounds such as $o$-aminophenol, $p$-aminophenol, sulfanilic acid and anthranilic acid, were all proved non-hemolytic.

Thus, as a result of this limited number of experiments, it may, at.least, be said that when $o$-aminophenol is diazotized and linked to protein, which is in itself devoid of hemolytic power, the resulting product acquires a new property, i.e.; the ability to lyse erythrocytes, as the same was the case with tuberculin.

Up to August, 1948, we could offer no explanation for this curious phenomenon. Very recently, it has however been shown by S. Koshimura that both $o$-aminophenol azo-histidine and $o$-aminophenol azo-tyrosine have a fairly high hemolytic power, $\dagger$ and from these observations it now becomes, at least, to be supposed that the presence of the intramolecularly situated groups of $o$-aminophenol azo-histidine and $o$-aminophenol azo-tyrosine is essential condition for the hemolytic property possessed by the above-mentioned $o$-aminophenol azo-protein derivatives. Further work is in progress to elucidate this question.

$\dagger$ In connection with these data, the work which was done by T. Okami (6) of this laboratory is particularly noteworthy: He found that $3,3^{\prime} ; 5,5^{\prime}$-tetrabromo-2; $2^{\prime}$-dihydroxy-azobenzene [I] possesses about the same hemolytic activity as does saponin, and that $2 ; 2$-dihydroxyazobenzene [II] itself is a slightly hemolytic agent.

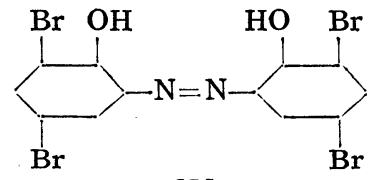

[I]

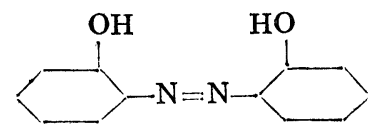

[II] 


\section{Conclusion}

Evidence has been presented for the phenomenon of acquiring hemolytic property of proteins by coupling them with diazotized $o$-aminophenol.

Prof. H. Okamoto deserves our thanks for continuous and invaluable help in this work. We are also indebted to Dr. W. L. Barksdale, 406 Medical General Laboratory in Tokyo, for encouragement and earnest attencion.

\section{REFERENCES}

1) Koshimura, S. and Ito, R.: Experimental study on the influence of azo-tuberculin upon guineapigs infected with tubercle bacilli. Jap. Med. J., (in press).

2) Okamoto, H., Kyoda, S. and Ito, R.: Ueber die hochgradige Steigerung des Hämotoxinbildungsvermögens des Streptococcus haemolycicus durch Nukleinsäure. (VII. Mict.) Weitere Ergebnisse der Untersuchung zur Darstellung hochgereinigter Strreptolysinpräparate. Jap. J. Med. Sci., IV. Pharmacology, 14, 99, 1941.

3) Ito, R., Okami, T. and Yoshimura, M.: Studies on the effect of nucleic acid upon the synthesis of oxygen stable streptolysin by certain strains of Streptococcus pyogenes. (Part XII) On the production of streptolysin by resting hemolytic streptococci suspended in nucleic acid solution. Jap. Med. J., 1, 245, 1948.

4) Ito, R., Okami, T., Yoshimura, M. and Sagara, S.: Studies on the effect of nucleic acid upon the synthesis of oxygen stable streptolysin by certain strains of Streptococcus pyogenes. (Part XIII) The inhibition of the production of hemolytic toxin of Streptococcus pyogenes by $\boldsymbol{o} ; \boldsymbol{o}$ '-dihydroxy-azobenzene and a related compound. Jap. Med J., 1, 260, 1948.

5) Kokuho, T.: Studies on the pharmacology of $o$-aminophenol. Annual Report of the Research Instituce of Tuberculosis, Kanazawa Medical University. 3, 57, 1945. (In Japanese)

6) Okami, T.: On the hemolytic action of tetrabromo-2;2'-dihydroxy-azobenzene. Folia Pharmacologica Japonica (in press). 